Dorota Grabowska

Warszawa

\title{
Józef Grycz - twórca przepisów katalogowania
}

Obecnie, w dobie komputerowych katalogów bibliotecznych, ISBD (International Standard Bibliographic Description), FRBR (Functional Requirements for Bibliographic Records, ISADN (International Standard Authority Data Number), VIAF (Virtual International Authority File) łatwo zapominamy o tym, jak trudne były początki katalogowania, że nie było ujednoliconych zasad opisu i że każda biblioteka opracowywała dokumenty według własnych zasad. W stworzenie w Polsce nowoczesnych zasad katalogowania wielki wkład wniósł Józef Grycz i to właśnie jego dorobkowi w tym zakresie jest poświęcony niniejszy artykuł.

Rok 1918 przyniósł Polsce odzyskanie niepodległości. Budowanie nowej rzeczywistości było bardzo trudne, długoletnie zaniedbania z okresu zaborów dawało się zauważyć w każdej dziedzinie, również w sytuacji bibliotek. Zbiory bibliotek były nieuporządkowane, nie istniały katalogi, a jeżeli istniały, to często były one niezrozumiałe. Sytuację ilustruje sparafrazowane przez Wacława Borowego powiedzenie Boya Żeleńskiego: „Ażeśmy zbrzydli Bogu bez katalogu” i dodał, że „nie tylko bez katalogu można obmierznąć, ale nawet i z katalogiem"1. Problem braku lub nieadekwatności katalogów dotyczył niemal każdej biblioteki. J. Grycz opracował sprawozdanie o sytuacji w Bibliotece Jagiellońskiej, gdzie możemy przeczytać: „Posiada ona trzy kartkowe katalogi alfabetyczne dzieł obcych, polskich niezmeliorowanych, polskich zmeliorowanych oraz skatalogowanych od r. 1906. Ale te katalogi nie zupełnie odpowiadają swemu przeznaczeniu, gdyż nie wszystkie kartki dawniejsze są zaopatrzone sygnaturą i szukać jej trzeba dopiero w dawnym, przez K. Estreichera zaprowadzonym, katalogu działowym"2. Nic wiec dziwnego, że bibliotekarze dużo uwagi zaczęli poświęcać tworzeniu przepi-

${ }^{1}$ W. Borowy, Prolegomena do wszelkiej przyszłej instrukcji katalogowej, Warszawa 1926, s. 7.

${ }^{2}$ Biblioteka Jagiellońska w latach 1918-1927, Przegl. Bibliot., 1:1927, s. 145. 
sów alfabetycznego katalogowania zbiorów. Początkowo poszczególne biblioteki i środowiska bibliotekarskie opracowywały własne instrukcje, chciały ujednolicić katalogowanie w obrębie swojej biblioteki, ułatwić dostęp do własnych zbiorów. Część z nich opublikowano, nabrały więc charakteru bardziej powszechnego. Zaczęło narastać przekonanie o konieczności stworzenia instrukcji krajowej, jednolitej dla wszystkich bibliotek w Polsce. Pojawiły się też pierwsze głosy o potrzebie wymiany kart katalogowych między różnymi krajami. J. Grycz był w grupie bibliotekarzy zainteresowanych powstaniem ogólnopolskiej instrukcji katalogowania. Jeszcze przed wyznaczeniem go przez Ministerstwo Wyznań Religijnych i Oświecenia Publicznego do opracowania wytycznych polskich przepisów katalogowania dzielił się swoimi poglądami w tej kwestii, pisząc do Adama Łysakowskiego (Kraków, 4 X 1926), że za najkorzystniejszą drogę ustanowienia ogólnopolskiej instrukcji uważa ankietę ${ }^{3}$. Twierdził, iż projekt powinno opracować jedno środowisko i rozesłać w odbitkach maszynowych do bibliotek, które zaproponują odpowiednie zmiany. Te z kolei rozpatrzą autorzy projektu, ewentualnie je uwzględnią i znów prześlą bibliotekom. Po ponownych poprawkach dokona się ostatecznej redakcji, którą zatwierdzi ministerstwo i zaprowadzi mocą dekretu lub rozporządzenia. Tak J. Grycz widział etapy powstawania ogólnopolskiej instrukcji katalogowania alfabetycznego. Jak poważnie traktował problem katalogowania może świadczyć fakt, że dokonał porównania pięciu instrukcji katalogowania spotykanych w Polsce: Przepisów katalogowania alfabetycznego $w$ bibliotekach polskich opracowanych przez Związek Bibliotekarzy Polskich, Instrukcji o katalogach alfabetycznych bibliotek naukowych - opracowanej przez Rudolfa Kotulę, zasad katalogowania obowiązujących w Bibliotece Jagiellońskiej opracowanych przez Edwarda Kuntzego, zasad katalogowania obowiązujących w Bibliotece Uniwersyteckiej w Warszawie zredagowanych przez Wacława Borowego i Instrukcji dla kierowników bibliotek wojskowych opracowanej przez Mariana Łodyńskiego ${ }^{4}$. Zauważył, że większość jednakowo normuje pracę katalogującego. Wskazał na niejasność m.in. w kwestiach: wyboru hasła, np. kiedy słowem porządkowym ma być nazwisko, a kiedy słowo pospolite wzięte $\mathrm{z}$ tytułu, w kwestii wyboru słów $\mathrm{z}$ tytułu, traktowanie nazwisk i imion, układania kart w katalogach. Po przeanalizowaniu istniejących między nimi różnic i podobieństw doszedł

3 Bibliotekarstwo polskie 1925-1951 w świetle korespondencji jego wspóttwórców, oprac. M. Dembowska. Warszawa 1995 [dalej cyt. Bibliotekarstwo polskie...], s. 203.

${ }^{4}$ J. Grycz, Porównanie polskich przepisów katalogowania, Kraków 1926. 
do wniosku, że żadna z nich nie mogłaby stać się instrukcją ogólnokrajową. Uważał, że powinna powstać nowa przez połączenie najsłuszniejszych zasad stosowanych w poszczególnych bibliotekach oraz niektórych przepisów zagranicznych. Postulował stworzenie jednolitych zasad katalogowania. Uważał, że trzeba dążyć się do utworzenia ośrodka katalogowego, który sporządzałby opisy katalogowe dla wszystkich zainteresowanych bibliotek, które otrzymywałyby takie opisy powielone. Podał przykłady zagraniczne: Bibliotheque Nationale w Paryżu, która dostarczała drukowanych kart katalogowych dla wszystkich druków francuskich i Staatsbibliothek w Berlinie, która drukowała karty katalogowe dla druków niemieckich. Zalecał korzystanie z kart drukowanych za granicą. W podobny sposób, jak przepisy krajowe, J. Grycz przeanalizował instrukcje katalogowania obowiązujące w innych krajach: pruską, angloamerykańską, francuską, włoską i czeską ${ }^{5}$.

Nie wszyscy ówcześni bibliotekarze zgadzali się z J. Gryczem, że potrzebna jest ogólnopolska instrukcja katalogowania. Na II Zjazd Bibliofilów (Warszawa, 1926) wydano drukiem referat Wacława Borowego, w którym autor podkreślał potrzebę katalogu alfabetycznego w bibliote$\mathrm{kach}^{6}$. Postulował, aby przyszła instrukcja miała przejrzysty układ i wyraźnie definiowała używane terminy (np. katalogowanie). Instrukcja powinna według niego odznaczać się poprawnością językową, trafnością doboru terminów, jasnością stylizacji (niezawiłymi zdaniami), dokładnością sformułowań (nie powinny to być zasady wymagające dużych wyjątków). Powinna zawierać dobre przykłady, ponieważ czasem nie udaje się czegoś trafnie sformułować, ale dobry przykład rozprasza całkowicie wątpliwości. Niemniej, Borowy był przeciwnikiem opracowania przepisów ogólnopolskich. Uważał, że ogólnopolska unifikacja katalogowania jest tylko pięknie brzmiącym, ale mało treściwym hasłem. Twierdził, że należy zająć się ustaleniem zasad katalogowania w obrębie poszczególnych bibliotek. Jest to przykład na to, że poglądy środowiska bibliotekarskiego były wówczas zróżnicowane. Jedni dostrzegali potrzebę tworzenia ogólnopolskiej instrukcji katalogowania i wspierali wysiłki J. Grycza, byli też tacy, którzy uważali to za utopię.

W wyniku dyskusji na II Zjeździe Bibliofilów Polskich uchwalono wniosek skierowany do Wydziału Bibliotek Państwowych Ministerstwa Wyznań Religijnych i Oświecenia Publicznego, wzywający do opracowania instruk-

5 J. Grycz, Porównanie zagranicznych przepisów katalogowania, Kraków 1929.

${ }^{6}$ W. Borowy, Prolegomena do wszelkiej przysztej instrukcji katalogowania, Warszawa 1926. 
cji ogólnopolskiej. Zwrócono się z prośbą, aby w porozumieniu z Radą Bibliotekarzy Polskich Wydział Bibliotek Państwowych zechciał rozpatrzyć istniejące instrukcje katalogowe i opracować w najbliższym czasie instrukcję obowiązującą wszystkie państwowe biblioteki polskie. Mimo głosów podających w wątpliwość sens tworzenia instrukcji krajowej, zwyciężył pogląd o potrzebie takich ujednoliceń. Był to początek żmudnej drogi w kierunku polskiej instrukcji alfabetycznego katalogowania zbiorów.

Na zlecenie Ministerstwa Wyznań Religijnych i Oświecenia Publicznego J. Grycz opracował Zasadnicze wytyczne polskich przepisów katalogowania, które w 1927 r. zostały zaakceptowane przez Wydział Bibliotek Państwowych. W tym samym czasie rozesłano je do zaopiniowania do trzynastu największych bibliotek państwowych i niepaństwowych. $\mathrm{Na}$ I Zjeździe Bibliotekarzy Polskich (Lwów, 1928) J. Grycz wygłosił referat pt. Ogólnopolska instrukcja dla sporzadzania alfabetycznych katalogów bibliotecznych. Przedstawił projekt ogólnopolskiej instrukcji, a wśród wniosków ze Zjazdu pojawił się postulat przyśpieszenia prac nad ogólnopolskimi przepisami katalogowania.

W pracach nad instrukcją wzięło udział trzynaście bibliotek naukowych. Do czerwca 1930 r. nadesłały one własne projekty, które stanowiły materiał do opracowania przez J. Grycza pierwszego projektu Przepisów katalogowania w bibliotekach polskich. W liście do A. Łysakowskiego J. Grycz pisał: „Przy tym kończę też nareszcie tę instrukcję. Zrobiłem już całość dotyczącą katalogowania, obecnie opracowuję szeregowanie kart i pozostaje jeszcze wybór przykładów. Mam nadzieję, że w sierpniu skończę, dam to we wrześniu powielić i roześlę do bibliotek. W grudniu będę chciał urządzić konferencję w Warszawie, o ile na czas dostanę opinie bibliotek"7 (3 VIII 1930).

Projekt rozesłany bibliotekom wywołał szereg kontrowersji. M. Lodyński zarzucał mu to, że jest pełen latynizmów i uważał, że należałoby go spolszczyć ${ }^{8}$ (22 XII 1930). A. Łysakowskiemu nie podobało się wprowadzenie autorstwa korporatywnego, które uważał za zbędne. Twierdził, że J. Grycz wprowadził fikcyjne hasła, które nic nie upraszczają. Zarzucał, że autor nic nie wie o Urzędowym Wykazie Druków oraz nie zna katalogu przedmiotowego. Krytykował również redakcję projektu twierdząc, że zawiera dużo wewnętrznych sprzeczności. Mimo wszystko dostrzegał postęp w pracach nad instrukcją . (29 XII 1930)

\footnotetext{
${ }^{7}$ Bibliotekarstwo polskie..., s. 212-213.

8 Tamże, s. 42.

${ }^{9}$ Tamże, s. 43-44.
} 
Nadesłane przez biblioteki opinie posłużyły J. Gryczowi do korekty projektu i stworzenia nowej wersji Instrukcji. Skarżył się na to, że opracowanie ankiet jest straszną pracą, że musi pójść na ustępstwa i stworzyć „projekt kompromisów”. Wybierał pomiędzy różnymi rozwiązaniami proponowanymi przez bibliotekarzy z Wilna, Lwowa, Krakowa i Warszawy. Było to tym trudniejsze, że każda ze stron swoje rozwiązania uważała za najsłuszniejsze. Przy dużych rozbieżnościach tworzył tablice najważniejszych odchyleń od Instrukcji.

Prace nad drugą wersją projektu trwały do 1 lipca 1931 r. J. Grycz w liście do A. Łysakowskiego ${ }^{10}$ (Zakopane, 25 VIII 1931) pisał, że uwzględnił $85 \%$ postulatów A. Łysakowskiego i R. Kotuli, i że dąży do tego, aby od 1 stycznia wprowadzić nową instrukcję. Zamierzenia stały się niemożliwe do wykonania w rzeczywistości. W październiku następnego roku powstała trzecia wersja projektu. Każda z nich była rozsyłana przez Ministerstw Wyznań Religijnych i Oświecenia Publicznego do bibliotek, które wyrażały swe krytyczne opinie. Uwagi nadsyłane przez biblioteki J. Grycz wykorzystywał przy redakcji następnej wersji przypisów. Skarżył się często na współpracę z bibliotekami. Narzekał na to, że nie przysyłają opinii na czas, że nie może zabrać się do pracy nie mając wszystkich ankiet. Prace nad instrukcją były bardzo żmudne i czasochłonne. Autor uwzględniał opinie bibliotek, nanosił zmiany, które niszczyły przejrzystą konstrukcję i za każdym razem musiał ją od nowa redagować. $\mathrm{O}$ pracach nad instrukcją informował bibliotekarzy. Na III Zjeździe Bibliotekarzy Polskich (Wilno, 1932) wygłosił referat: Na drodze do polskich instrukcji alfabetycznego katalogowania ${ }^{11}$. Ostatnia wersja instrukcji12 została zatwierdzona przez Ministerstwo Wyznań Religijnych i Oświecenia Publicznego, jako obowiązująca w państwowych bibliotekach naukowych całego kraju od 1 czerwca 1934 r.

Po ukończeniu prac nad instrukcją J. Grycz wyraził krytykę przyjętej metody ankietyzacji, która bardzo przedłużyła prace nad instrukcją. Uważał, że dużo lepszym rozwiązaniem byłoby powołanie 2-3 osobowej komisji i nieuwzględnianie opinii środowiska bibliotekarskiego, a odpowiedzialność ponieśliby wtedy twórcy.

Ostateczna wersja instrukcji nie zdobyła całkowitego poparcia bibliotekarzy. Autor wiedział o tym, ale równocześnie zdawał sobie sprawę, że

10 Tamże, s. 216-217.

${ }^{11}$ Pamiętnik Trzeciego Zjazdu Bibliotekarzy Polskich w Wilnie, 26-28 VI 1932 r., Kraków 1932.

12 J. Grycz, Przepisy katalogowania w bibliotekach polskich. I. Alfabetyczny katalog druków, Warszawa 1934. 
w tej kwestii wszystkich nie zadowoli. Łysakowski po zapoznaniu się z ostateczną wersją instrukcji, rozesłał swoje krytyczne opinie innym bibliotekom. J. Grycz był zaskoczony taką reakcją, tłumaczył, że instrukcja może być korygowana, a praktyka pokaże, jakie ma wady.

W części wstępnej przepisów J. Grycz podał definicję katalogu, określił jego zadania i funkcje. Ustalił, że jednostką katalogową powinien być egzemplarz druku odrębnego bibliograficznie i typograficznie, który pod względem piśmienniczym i wydawniczym jest samoistną całością. J. Grycz wyróżnił też poszczególne typy wydawnictw. Omówił dokładnie rodzaje opisów katalogowych (główne i pomocnicze) oraz ich części składowe i funkcje.

W dalszej części Przepisów katalogowania w bibliotekach polskich podał szczegółowe zasady opisu wydawnictwa. Omawiał wszystkie jego elementy od wyboru hasła, aż do adresu wydawniczego i uwag bibliograficznych. Według J. Grycza hasło autorskie przysługiwało dziełu jednego, dwóch lub najwyżej trzech autorów. Na podstawie rozszerzonego pojęcia autorstwa zalecił stosowanie hasła osobowego dla zbiorów drobnych utworów, prac zebranych przez wydawcę naukowego lub redaktora, czyli antologii, zbiorów tłumaczeń, chrestomatii ${ }^{13}$. Hasłem wydawnictw anonimowych, zbiorowych oraz ciągłych był pierwszy rzeczownik tytułu lub wyraz użyty rzeczownikowo podany w mianowniku, według najnowszej pisowni. Jest to wyraźny wpływ niemieckich zasad katalogowania. A. Łysakowski właśnie to uznał za największy mankament tej instrukcji w swojej recenzji ${ }^{14}$. Wydawnictwa wielotomowe i ciągłe, zmieniające tytuł w dalszych tomach J. Grycz zalecał grupować pod hasłem zaczerpniętym z pierwszego tomu. Odrzucił hasło korporatywne. W tym również należy dopatrywać się wpływu niemieckich zasad katalogowania. Wprowadził tzw. grupy formalne, które powinny być stosowane dla wydawnictw szkolnych, zawierających spisy osób, programy oraz dla sprawozdań ciał zbiorowych i instytucji. Zalecał podawanie haseł, zwłaszcza osobowych, w formie oryginalnej. Dla ułatwienia katalogowania zamieścił $\mathrm{w}$ instrukcji tablice transliteracyjne $\mathrm{z}$ alfabetów niełacińskich. Zawarł też w swych przypisach „hierarchię języków”, która miała bibliotekarzom ułatwiać dokonanie wyboru w przypadku występowania w wydawnictwach tytułów w różnych językach. Za duży plus Przepisów katalogowania książek $w$ bibliotekach polskich należy uznać sporą liczbę przykładów tam umieszczonych, ułatwiały one interpretację zasad.

${ }^{13}$ Chrestomatia - zbiór próbek i wzorów - głównie prozy.

${ }^{14}$ A. Łysakowski [rec. z:] Przepisy katalogowania w bibliotekach polskich. I. Alfabetyczny katalog druków, Przegl. Bibliot., 8:1934, z. 3, s. 169-182. 
W 1934 r. wyszła drukiem ostateczna redakcja Przepisów katalogowania w bibliotekach polskich. I. Alfabetyczny katalog druków. Była to pierwsza w Polsce instrukcja katalogowania. Niestety, do wybuchu II wojny światowej jej postanowienia nie zostały do końca wprowadzone w praktyce bibliotekarskiej. Melioracja istniejących katalogów była bardzo czasochłonna, zwłaszcza, że panował w nich bałagan. Właściwie dopiero po wojnie zaczęto stosować jednolite zasady przy opracowywaniu zbiorów.

\section{Ujednolicanie zasad katalogowania alfabetycznego po 1945 r. „Skrócone przepisy katalogowania” Józefa Grycza i Władysławy Borkowskiej}

Przedwojenny wysiłek J. Grycza nie poszedł na marne, w 1946 r. ukazało się pierwsze wydanie Skróconych przepisów katalogowania alfabetycznego $o^{15}$. Autor był przekonany o konieczności istnienia dwóch instrukcji katalogowych: dla bibliotek dużych, naukowych oraz dla bibliotek mniejszych. Jedna miała być obszerna, rozbudowana, a druga skrócona, stosowana przede wszystkim przez biblioteki powszechne. Obie miały opierać się na tych samych podstawach, powinny przestrzegać jednolitości sposobu katalogowania, co ułatwiłoby pracę bibliotekarzom i korzystanie z bibliotek czytelnikom. J. Grycz był wierny idei ogólnokrajowego ujednolicenia opisu katalogowego. Dostrzegał jednak różnorodność bibliotek i odmienne potrzeby użytkowników, także jeżeli chodzi o szczegółowość opisu katalogowego.

Skrócone przepisy katalogowania alfabetycznego (dalej: Skrócone przepisy...) były zbliżone do przedwojennych Przepisów katalogowania, miały ten sam układ i dotyczyły tych samych zagadnień. Uwzględniały dotychczasowe doświadczenia i w związku z tym zawierały pewne zmiany. Sam autor tłumaczył się, że wszelkie zmiany wprowadzał bardzo ostrożnie i tylko wtedy, kiedy były one uzasadnione. Uważał, że zniszczenia wojenne dawały, w tym wypadku, korzystną możliwość tworzenia od podstaw ujednoliconych katalogów bibliotecznych, stąd tak szybko po wojnie ukazały się Skrócone przepisy... J. Grycz liczył na to, że wszyscy będą stosować ujednolicone zasady. Zmiany wprowadził przy wyborze hasła tytułowego anonimów. Naczelnym wyrazem hasła tytułowego miał być pierwszy wyraz druku, z pominięciem:

- rodzajników,

15 J. Grycz, Skrócone przepisy katalogowania alfabetycznego, Warszawa 1946. 
- liczebników porządkowych, wskazujących tylko chronologię powstania druku,

- formuł wstępnych, które zapowiadają tytuł i nie wchodzą w jego skład

- wyrazów oznaczających tylko objętość druku lub jego przynależność do pewnej całości.

Autor zalecał, aby biblioteki powszechne porządkowały karty katalogowe według alfabetu polskiego, a biblioteki naukowe miały przyjąć alfabet łaciński. W tej kwestii można mówić o braku konsekwencji w dążeniu do ujednolicenia zasad katalogowania. Zalecenie stosowania różnych alfabetów przy porządkowaniu opisów stwarzało kłopoty przy wyszukiwaniu informacji.

J. Grycz w przedmowie umieścił wytyczne, według których należało porządkować opisy. Zasadniczo są to cztery zasady. Pierwsza mówiła o umieszczaniu oddzielnych opisów katalogowych pod takimi samymi wyrazami porządkowymi, czyli „hasłami”. Miały to być przede wszystkim nazwiska. Gdy hasłem nie mogło być nazwisko i trzeba było umieścić druk pod hasłem tytułowym, wówczas hasłem stawał się pierwszy wyraz tytułu, a dalej mechanicznie dalsze wyrazy tytułu. Druga zasada mówiła o skupieniu tych samych haseł w jednym miejscu w katalogu, co wymagało umieszczania poszczególnych osób pod jedną nazwą, nadając im tę samą formę, a wyrazy pospolite należało pisać według obowiązującej pisowni, a od form nieodmiennych, użytych w druku, należało odsyłać do form przyjętych w haśle. Trzecia zasada dotyczyła przejrzystości katalogu. Odpis tytułu miał być ograniczony do danych istotnych, niezbędnych do szybkiego i pewnego rozpoznania i odróżnienia danego druku lub jego wydania od innych druków lub wydań tego samego utworu. Zakładano nawet, że zbyt rozległe tytuły będzie się skracać, niejasne zaś uzupełniać. Czwarta zasada wyszczególniała w katalogu posiadane egzemplarze druków, a nie jak to było w bibliografii, oddzielne publikacje.

J. Grycz wyróżnił następujące typy dokumentów, które mogą wystąpić w katalogu:

- wydawnictwa zamknięte (zwarte),

- wydawnictwa ciągłe,

- druki ulotne.

Do wydawnictw zwartych zaliczał dzieła ukazujące się w druku w od razu skończonej postaci, a do dzieł wielotomowych lub wydawnictw zeszytowych te, których zakończenie nie było z góry przewidziane przez wydawcę. Wyróżniał wśród nich: 
- dzieła zbiorowe (więcej niż trzech autorów),

- jednego, dwu lub trzech autorów,

- dzieła autora domniemanego,

- dzieła anonimowe, których autorów nie można wyśledzić.

Wydawnictwa ciągłe charakteryzowal, jako te, które wychodzą częściami w regularnych lub też nieokreślonych odstępach czasu, przy czym zakończenia ich się nie przewiduje. Zaliczył do nich:

- wydawnictwa periodyczne,

- wydawnictwa zbiorowe,

- wydawnictwa seryjne.

Do wydawnictw periodycznych zaliczył gazety, czasopisma, kalendarze, księgi adresowe, spisy i wykazy dotyczące pewnych czasokresów (np. sprawozdania, spisy wykładów uniwersyteckich, wykazy nabytków bibliotecznych itp.). Uznał, że periodyki mają zasadniczo ten sam tytuł ogólny, wspólny dla wszystkich części (zeszytów, tomów). Jako cechę szczególną wymienił kolejną numerację poszczególnych części danego wydawnictwa albo też podawanie czasokresu, którego dana część dotyczy.

Przedstawił również definicję czasopisma i gazety, za wyróżniającą je cechę uznał to, że poszczególne ich części zawierają z reguły utwory na rozmaite tematy, przede wszystkim aktualne, pisane przez liczne, zmieniające się zespoły współpracowników, często (zwłaszcza w gazetach) bez wymieniania ich nazwisk. Wskazywał na to, że czasopisma wychodzą w większych odstępach czasu niż gazety, zazwyczaj z pewnego określonego zakresu. Jako uboczne kryterium odróżniania czasopism i gazet podał postać zewnętrzną.

Za wydawnictwa zbiorowe uznał te, które składają się z tomów, obejmujących prace różnych autorów, publikowanych pod wspólnym tytułem głównym.

Wydawnictwa seryjne przedstawił jako te, które składają się z odrębnych samoistnych dzieł różnych autorów połączonych w jedną całość wydawniczą wspólnym tytułem zbiorowym i zazwyczaj kolejną numeracją. Poszczególne części posiadają własne tytuły, które są ich tytułami głównymi.

Za druki ulotne uznawał: ogłoszenia, wywieszki, afisze, plakaty, programy widowisk i koncertów, drobne jedno lub parostronicowe druki okolicznościowe, propagandowe, reklamowe itd. Mają one znaczenie doraźne, przejściowe, są wydawane przez zbiorowości, których dotyczą.

Mimo, że dużo miejsca poświęcił scharakteryzowaniu poszczególnych typów dokumentów, instrukcja dotyczy przede wszystkim książek. Czasopismom poświęcił kilka stron (sześć), a jedną drukom ulotnym. 
J. Grycz zdawał sobie sprawę, że Skrócone przepisy stanowią zbiór suchych reguł, które zainteresowany będzie musiał zinterpretować i zastosować. Ilość przykładów uznał za niewystarczającą, wiedział, że zawsze można natknąć się na jeszcze inny przypadek, nie dający podciągnąć się pod żadną z omówionych reguł. Mimo swoich niedociągnięć dzieło to służyło przez wiele lat jako podręcznik uczący katalogowania i długo nie miało swojego następcy.

Katalog według J. Grycza powinien odpowiadać na dwa pytania: czy dane dzieło jest w bibliotece i gdzie się ono znajduje. Na pierwsze pytanie powinien odpowiadać opis katalogowy, a na drugie sygnatura (specjalne znaki symboliczne). Zalecał, aby każdy egzemplarz otrzymywał oddzielny opis katalogowy i osobną sygnaturę. Wyjątek czynił dla całkowicie identycznych egzemplarzy (także pod względem postaci zewnętrznej i wykonania), które pozwalał umieszczać na jednym opisie katalogowym, zaopatrując go i poszczególne egzemplarze w osobne sygnatury indywidualne. Wyjaśniał również sposób porządkowania opisów katalogowych. Zalecał układać je w porządku alfabetycznym „haseł”. Hasła stanowiły nazwy autorów - hasła autorskie, bądź wyrazy zaczerpnięte z tytułu - hasła tytułowe. Nie uwzględnił w instrukcji nut, rycin, map, inkunabułów, uznał, że powinno się je katalogować według odrębnych przepisów. Tłumaczył, że stworzone zasady należy stosować do druków, których istotną cechę stanowi tekst słowny. Dopuszczał sporządzanie katalogów pomocniczych np. czytelni, sposobem uproszczonym, uwzględniając tylko najpotrzebniejsze dane o poszczególnych drukach. Nie wymienił niezbędnych elementów opisu, ani elementów, które można pomijać, apelował jedynie do przestrzegania zasadniczych wytycznych.

W styczniu 1948 r. ukazało się drugie wydanie Skróconych przepisów. Przy ich redagowaniu J. Gryczowi pomagała W. Borkowska. Autorzy bardzo ostrożnie wprowadzali zmiany, uzasadniając to tym, że wszelkie innowacje pociągają za sobą obowiązek przerabiania katalogów bibliotecznych. Za ważniejsze niż tworzenie idealnego katalogu, przez ciągłe ulepszanie przepisów jego opracowywania, uznali trzymanie się jednolitych zasad katalogowania. Praktyka zmusiła ich jednak do wprowadzenia pewnych zmian, główny jednak nacisk położyli na usunięcie błędów i pomyłek, jaśniejszą stylizację oraz rewizję przykładów. Kolejne wydania Skróconych przepisów przygotowywała W. Borkowska. Mimo że za każdym następnym wydaniem zapowiadano ukazanie się „dużych” przepisów katalogowania doczekaliśmy się sześciu wznowień (1946, 1448, 1960, 1969, 1975). Spowodowane to było wyczerpaniem nakładów poprzedniego wydania, ale również ciągłym zapotrzebowaniem na 
podręcznik do szkolenia nowej kadry. Termin wydania „dużych” przepisów ciągle odwlekano. W kolejnych wznowieniach starano się nie wprowadzać radykalnych zmian, jedynie poprawiać błędy i przeprowadzać rewizję przykładów. Zmiany jednak były, pojawiały się nowe przykłady, uwzględniano również ukazujące się w międzyczasie ustalenia normalizacyjne. Komisja Bibliograficzno - Bibliotekarska PKN w 1952 r. opracowała normę PN/N-09006 (karty katalogowe czasopism) obowiązująca od 1 kwietnia 1955 r. Uwzględniono również normy: PN-57/N-01158 skróty wyrażeń typowych (polskich i obcych często używanych w opisie bibliograficznym i katalogowym) i PN-59/N-01201. Z tej ostatniej uwzględniono tablice transliteracyjne. Tablice alfabetu greckiego wzorowano na projekcie Międzynarodowej Organizacji Normalizacyjnej (ISO) z 1959 r. Czwarte wydanie Skróconych przepisów pojawiło się osiem lat później. Znowu powoływano się na „obszerne” przepisy, które miały się ukazać, ale termin wydania przedłużał się. Zmiany były nieznaczne, wręcz W. Borkowska zgodziła się na wznowienie, pod warunkiem nie wprowadzania radykalnych zmian. Podobna sytuacja była z piątym i szóstym wydaniem. Poprawiano błędy, wprowadzano nowe, aktualne przykłady, uwzględniano zalecenia nowych norm np. dotyczących transliteracji. Szóste wydanie uwzględnia normy transliteracji:

- PN-70/N-01201 Transliteracja stowiańskich alfabetów cyrylickich (obowiązująca od 1 I 1971),

- PN-72/N-01203 Transliteracja alfabetu greckiego (obowiązująca od 1 I 1973),

- PN-74/N-01211 Transliteracja alfabetu hebrajskiego (obowiązująca od 1 VII 1975),

- PN-74/N-01212 Transliteracja pisma jidysz (obowiązująca od 1 VII 1975),

- PN-70/N-01158 Skróty wyrazów typowych w opisie bibliograficznym i katalogowym (obowiązująca od 1 VII 1971).

Z norm dokonano wyboru skrótów wyrazów typowych najczęściej używanych w opisie katalogowym

- PN-68/N-01178 Skróty wyrazów w tytułach czasopism $i$ wydawnictwach zbiorowych (obowiązująca od 1 VII 1969).

W Skróconych przepisach ${ }^{16}$ J. Grycz i W. Borkowska omawiają wszystkie zasady katalogowania: budowę katalogu, dobór i formułowanie haseł oraz opis bibliograficzny. Instrukcja dotyczy katalogów kartkowych, zalecano sporządzanie opisów na luźnych kartach jednakowego formatu.

${ }^{16}$ Omówienia dokonałam na podstawie wydania VI (ostatniego). 
Szczegółowo wyjaśniono jak należy podzielić kartę, gdzie umieścić sygnaturę i hasło. Przedstawiono wzór pisma bibliotecznego, którym należało wypisywać karty katalogowe, jeżeli nie korzystano z maszyny do pisania. Karty katalogowe podzielono na karty główne i karty pomocnicze. Zalecano stosowanie odsyłaczy: ogólnych autorski, ogólnych tytułowych, szczegółowy autorski, dla nazw miejscowości, szczegółowych tytułowy. Zalecano również stosowanie kart zbiorowych, które zawierały wykazy znajdujących się w bibliotece części danego wydawnictwa seryjnego.

Wyróżniono dwa typy haseł: autorskie (podane w druku lub wykryte nazwy autorów) i tytułowe (określone wyrazy, zaczerpnięte przede wszystkim z tytułu katalogowanego druku).

Skrócone przepisy funkcjonowały w Polsce ponad 40 lat. Przez tak długi okres posługiwano się nimi przy wyborze haseł. Dlatego wkład J. Grycza w ujednolicanie zasad katalogowania w Polsce jest bardzo znaczący. $\mathrm{Z}$ czasem rozwiązania krajowe zostały wyparte przez zalecenia międzynarodowe, które stały się podstawą krajowych instrukcji katalogowania.

\section{Streszczenie}

\section{Józef Grycz - twórca przepisów katalogowania}

Celem artykułu jest ukazanie wkładu Józefa Grycza w ujednolicenie zasad katalogowania w Polsce. Przeanalizowano jego korespondencję z czołowymi ówczesnymi bibliotekarzami, co pozwoliło odtworzyć działania, które doprowadziły do wydania Przepisów katalogowania w bibliotekach polskich w 1934 r. Przedwojenny wysiłek przyczynił się do publikacji w 1946 r. pierwszego wydania Skróconych przepisów katalogowania alfabetycznego. Potem ukazywały się kolejne wydania, przy których pomagała W. Borkowska.

W artykule scharakteryzowano najważniejsze problemy doprecyzowywane w przepisach katalogowania. Skrócone przepisy funkcjonowały w Polsce ponad 40 lat. Przez tak długi okres posługiwano się nimi przy wyborze hasła. W czasach komputeryzacji i norm warto pamiętać o trudnych początkach i twórcy przepisów katalogowania.

\section{Summary}

\section{Józef Grycz: The Creator of Polish Library Cataloguing Regulations}

The article aims at demonstrating the input of Józef Grycz into the unification of cataloguing rules in Polish libraries. To this end the author analyzed Grycz's cor- 
respondence with other leading Polish librarians. This allowed for the reconstruction of his activities, which resulted in the publishing of the Cataloguing Rules for Polish Libraries in 1934. The experience gained during the interwar period proved beneficial for Grycz's second cataloguing manual, published in 1946 (Abbreviated Regulations for Alphabetical Cataloguing). This book was reprinted many times in the following years. In preparing the later editions, Grycz was assisted by W. Borkowska.

The article also discusses the most important issues settled by the rules worked out by Grycz. The Abbreviated Regulations... provided the basis for cataloguing activities in Poland for over forty years and dictated the choices of headings. Nowadays, when computer cataloguing is the normal and natural procedure, it is well worth to keep in mind how difficult were the beginnings, and to remember the person who paved the way towards modern cataloguing. 
